\title{
Energy Demand and Supply Forecasting Based on Electricity Consumption Intensity and Production Capacity for Development of Operating Support in Headquarter of Indonesian National Army
}

\author{
Budi Nur Cahyo ${ }^{1}$, Ahmad Agus Setiawan ${ }^{1}$, Wahyu Wilopo ${ }^{1}$, Afrizal Abdi Musyafiq ${ }^{2 *}$ \\ ${ }^{1}$ Department of System Engineering, Universitas Gadjah Mada, Yogyakarta - Indonesia \\ ${ }^{2}$ Department of Electrical Engineering, Universitas Nahdlatul Ulama Yogyakarta, Indonesia
}

\begin{abstract}
Indonesia is one of the major countries composed of many islands; directly adjacent to several neighboring countries; and is also a country with a large population in the world. The security and resilience of the state of threats coming from abroad and within the country would have been anticipated by a government agency namely the Indonesian National Army (TNI). The TNI in performing its duties must be supported by means of supporting facilities for operations at headquarters. Supporting facilities for operations at the TNI Headquarters should have enough energy, especially on the need for electrical energy. The need for electrical energy at the TNI Headquarters is fully supported by the State Electricity Company (PLN). In this research will take into account the needs of Tower A and underground at TNI Headquarters which will be built with low voltage building planning. Analysis using LEAP to estimate demand and energy needs lsitrik at TNI Headquarters in order to experience the energy balance. The end result of this research is to provide recommendations to the TNI ranks regarding the capacity building of the necessary operational facilities at the TNI Headquarters.
\end{abstract}

Keywords: forecasting; energy demand and supply; LEAP; TNI Headquarters.

\section{Introduction}

Development in Indonesia is being intensified by campaigns for government buildings that must have low carbon characteristics. Possible things in the use of energy for the process. Energy resilience is very important for the smooth livelihood of many people in doing all activities every day [1]. An activity will be so easy to do when the need for all of its energies is fulfilled. Achieving sufficient energy must of course be planned a good energy system. A good energy system should pay attention to the demand and supply of sufficient energy [2]. Sufficient energy demand and supply can cause the balance of energy needs to be balanced. It causes a need for energy will be achieved in all circumstances [3]. All countries in the world must prepare their respective energy security [4]. It aims to a process of life in it can run well in the present and in the future [5]. Indonesia is one of the countries that has prepared its energy planning process perfectly [6]. It aims to avoid the occurrence of energy crisis in the future and can take advantage of all the natural resources potential of Indonesia as a sustainable energy source of the future [7].

Indonesia is one of the major countries composed of many islands; directly adjacent to several neighboring countries; and is also a country with a large population in the world. All government activities are run in the capital city of Indonesia which is located in DKI Jakarta. DKI Jakarta is one of the provinces in Java Island with an area of $662.33 \mathrm{~km} 2$ and the total population reaches $10,177,924$ inhabitants. Based on data from the Badan Pusat Statistika (BPS) in 2017, population growth in Jakarta Capital City reached $1.09 \%$ with economic growth reaching $6.02 \%$ in the last five years. Energy security and resilience in DKI Jakarta is one of the main sectors that must be fulfilled by the Indonesian government for the smoothness of all state administration affairs [8]. Another thing to note is on the security and resilience of the state in ring area 1 , because all state officials from the executive, legislative, and judicative residing in DKI Jakarta [9].

The security and resilience of the state of threats coming from abroad in the form of terrorist attacks and the country in the form of separatist separatist movement of the Unitary State of the Republic of Indonesia (NKRI) must have been anticipated by a government institution/agency in the field of the Indonesian National Army (TNI) [10]. TNI is an institution led directly by the commander of TNI 4 (four) under the order of the President has a place called TNI Headquarters

* Corresponding author: afrizal.adbi.m@gmail.com 
(Headquarter) in Cilangkap Jakarta. TNI headquarters consist of 3 (three) path TNI including Army (AD) [11], Navy (AL) [12], and Air Force (AU) [13].

TNI in performing its duty must be supported by infrastructure supporting facilities at TNI Headquarters, it is necessary for the threat or the worst situation regarding the security of the country can be minimized and even avoided [14]. Supporting facilities for operations at the TNI Headquarter itself must have enough energy, especially on the need for electrical energy as a support tool in conducting and assisting the activities of all stakeholders in TNI Headquarters can run well and smoothly [15]. Energy security in TNI HQ is of course very influential to the demand and energy needs as supporting the means of operation [16]. The need for electrical energy at TNI Headquarters is fully supported by PT. State Electricity Company (PLN), so that things that are not desirable like a power outage at any time by PLN can be avoided. Until now, the need for electrical energy TNI Headquarter still experience surplus energy. Electricity capacity of PLN can be used for the development of facilities of Tower A and underground at TNI Headquarters.

In this study will take into account the needs of Tower $\mathrm{A}$ and underground at TNI Headquarters to be built with low energy building planning. Analysis using LEAP (Long-range Energy Alternatives Planning system) to estimate demand and energy needs listrik in TNI Headquarters in order to experience the energy balance from the addition of operating facilities. The end result of this research is to provide recommendations to the TNI ranks regarding the capacity building of the necessary operational facilities at the TNI Headquarters.

\section{Methodology}

LEAP is a computer software that can be used as a modeling tool with a comprehensive scenario based on environment and energy [17]. The software was developed at the Stockholm Environment Institute (SEI), Boston, USA. LEAP is able to assemble scenarios for how much energy consumption is used, converted, and produced in an energy system with various alternative population assumptions, economic development, technology, prices, and so forth. This makes it easy for users of this software to gain flexibility, transparency, and convenience [18]. LEAP is not only a tool of calculation and analysis, but also can adjust the user's desires by determining other calculation models based on econometrics. Users can perform combinations and match these methodologies as required in an analysis [19].

LEAP supports for projections of final energy demand and demand for energy being used in detail including energy reserves, transportation, and so forth. On the supply side, LEAP supports a variety of simulation methods for modeling both capacity expansion and delivery processes from plants. In LEAP there is a database of Technology and Environmental Database (TED) containing data on cost, performance, and emission factors of more than 1000 energy technologies [20]. LEAP can be used to calculate emission profiles and can also be used to create emissions scenarios from the non-energy sector. LEAP has features designed to create and create scenarios, manage and document data and assumptions, and view reporting results easily and flexibly [21]. The results of LEAP can be reports that provide information that we can further analyze. Such reports may take the form of data or tables or diagrams [22].

The modeling methodology in LEAP is accounting. The energy demand in this method is calculated as the product of the total activity of energy consumption and the energy intensity. The calculation of energy demand is done by using the following equation:

$E D b, s, t=T A b, s, t \times E I b, s, t$

where $E D$ is electricity demand, TA is total activity, $E I$ is electricity intensity, $b$ is branch (sector of customer), $s$ is scenario, and $t$ is time (year). While the energy intensity is the average annual energy consumption per unit activity. Energy elasticity is the ratio of growth of energy consumption to product or output growth. The output growth is usually a GDP growth or a regional GDP [23].

The energy elasticity is expressed in $\mathrm{kWh} / \mathrm{Million}$ rupiah, while the growth of energy consumption is expressed in $\mathrm{kWh}$ units and GDP growth in million rupiah. The lower the elasticity, the more efficient the use of energy. With the current economic growth and electricity consumption in Indonesia, the elasticity rate is more than 1 , while for the developed countries average is 0.5. Economic growth in developed countries is two times higher than the growth of electricity consumption [24]. LEAP processing to analyze the demand and demand of electric energy in Jakarta area as a whole. Here is an explanation of the energy management methods used in this study:

\subsection{Approach end-use}

The end-use approach model is also known as the engineering model approach. This approach will be more detailed even though the calculation uses a simpler function [25]. The technological considerations used in the energy flow process also become the calculation variable. This approach is well suited for the purposes of energy efficiency projection because it is possible to explicitly consider technological changes and service levels [26].

The energy demand of each activity is a product of two factors, ie activity level (energy service) and energy intensity (energy use per unit of energy services) [27]. In addition, the total demand and demand for sectoral energy is influenced by the breakdown of different activities that make up the composition or the structural demand for energy [28]. To determine the amount of energy consumption, we can see in the following equation

Finergy C.mantmption $=\sum_{i=1}^{i=n} \eta_{i} \cdot I_{i}$ 
Where $Q i$ is he amount of energy services, and $I i$ is intensity of energy use for energy services (kWh / number of services). The amount of energy activity depends on several factors, including the population size, the proportion of the final use of energy, the energy consumption pattern, and in certain circumstances where the division is required on the user or customer classification [29].

\subsection{Approach DKL 3.2 (Daftar Kebutuhan Listrik)}

The DKL Method 3.2 uses an approach that combines the analysis of power sales statistics and economic growth presented with Gross Regional Domestic Product (GDP) [30]. In general, the growth of the population's need for electrical energy is certainly related to the increasing population in an area. With the growing population, indirectly will lead to an increase in the number of electricity subscribers in the area and also increase the development of various industrial sectors which of course required greater electrical energy [31]. The following are the DKL Model 3.2 formulas.

calculate household electrical energy can use the following formula [32]:

$$
E \cdot R T=E \cdot R T_{-1}\left(1+e R T \times \frac{g E}{100}\right)+\Delta P R T \times U
$$

Where E.RT is Household electrical energy quantity, $E . R T_{-I}$ is amount of Household electrical energy before, $g E$ is total GDP growth, $\triangle P R T$ is difference of PRT, $U K$ is unit consumpstion, and $e R T$ is elasticity. calculate the electrical energy of the public sector can use the following formula [32]:

$$
E \cdot P=E \cdot P_{-1}\left(1+e P \times \frac{g P}{100}\right)
$$

Where E.P is the amount of Public electric energy, E. $P_{-1}$ is the amount of public electricity before, $g P$ is growth of Public GDP, and $e P$ is elasticity. After obtaining the value of the sum of the electrical energy of each sector, we can project the energy produced and also the peak load by the following formula:

$$
\begin{aligned}
& P t=\frac{E t}{(1-L t)} \\
& E t=E . R T+E . P \\
& P L=\frac{P t}{(8760 \times L F)}
\end{aligned}
$$

Where $P t$ is energy production, Et is Total energy consumption, Lt is Transmission and distribution losses, $P L$ is Peak load, $L F$ is load factor

\subsection{Scenario}

Indicators to be considered in the preparation of this research are macroeconomic indicators, energy, demography, and energy policy. The projection period starts in 2016 until 2050, it is done because of the last data link obtained from BPS DKI Jakarta. By the year 2050 , is the year chosen to know the development of government policy 25 years ahead because that year can be seen result from government policy according to Government Regulation Number 79 Year 2014 About National Energy Policy mentioned that the use of national energy mixture is targeted to reach $23 \%$ in year 2025 The assumptions used in this simulation are:

1. Population growth for the period 2016 - 2050 follows the projection of population growth according to RPJPD DKI Jakarta 2005-2025 adjusted with projected population of BPS 2016 - 2040, then projected based on growth trend until 2050.

2. Economic growth follows the trend of economic growth $2011-2015$ which is adjusted to the provincial economic growth plan based on RPJPD DKI Jakarta 2005-2025.

3. The electrification ratio is targeted $100 \%$ by 2020 according to government target

The projection of energy demand is done by using two approaches, namely Bussiness Usual Scenario $(\mathrm{BaU})$ and National Energy Policy Scenario (KEN). It is to know the comparison on both scenarios that have been made. The BaU scenario is the current state without any changes to the prevailing policies and other interventions. The KEN scenario is a basic scenario where it is assumed that final energy consumption will be reduced by applying conservation and energy efficiency programs in accordance with government targets in national energy policy.

Table 1. Differences in BaU scenarios and KEN scenarios

\begin{tabular}{|l|l|}
\hline \multicolumn{1}{|c|}{ Bussiness as Usual (BaU) } & $\begin{array}{c}\text { Kebijakan Energi Nasional } \\
\text { (KEN) }\end{array}$ \\
\hline $\begin{array}{l}\text { Energy demand follows } \\
\text { DKL 3.2 projection }\end{array}$ & $\begin{array}{l}\text { The assumption is the same } \\
\text { as BaU }\end{array}$ \\
\hline $\begin{array}{l}\text { Construction of new plants } \\
\text { under RUPTL 2016 - 2025 } \\
\text { runs all according to plan }\end{array}$ & $\begin{array}{l}\text { The assumption is the same } \\
\text { as BaU }\end{array}$ \\
\hline $\begin{array}{l}\text { Utilization of renewable } \\
\text { energy (RE) is not yet } \\
\text { optimal }\end{array}$ & $\begin{array}{l}\text { Maximize all potential of } \\
\text { RE, including nuclear }\end{array}$ \\
\hline $\begin{array}{l}\text { Application of energy- } \\
\text { saving technology is not } \\
\text { optimal yet }\end{array}$ & $\begin{array}{l}\text { All sectors of energy use } \\
\text { have applied energy-saving } \\
\text { technology optimally }\end{array}$ \\
\hline $\begin{array}{l}\text { Diesel power plants (PLTD) } \\
\text { are still the main energy } \\
\text { source }\end{array}$ & $\begin{array}{l}\text { PLTD is just a backup } \\
\text { generator }\end{array}$ \\
\hline
\end{tabular}

\section{Results and discussion}

\subsection{Scenario analysis BaU and KEN}

The process of collecting data that has been done and continued with data processing to get the data projection calculation of the trend of secondary data available. The 
data are then used as input on LEAP application so that outputs are obtained in the form of general description of demand and demand of electric energy in DKI Jakarta Province. The data presented explains the projection of the population growth rate, the growth of GRDP, the need of all energy in the area of DKI Jakarta Province, as well as the demand for electrical energy in the area of DKI Jakarta Province. Fig 1. and Fig 2. explaining about the output of research in the form of graphs that resulted from data processing with LEAP application.

Fig 1. explained about the need of all energy in the province of DKI Jakarta in the Scenario of $\mathrm{BaU}$ and KEN. The need for all these energy means that energy has not been transformed to other forms of energy such as for electrical energy and transportation. Based on the $\mathrm{BaU}$ and KEN scenario, there is a similarity in the value of energy demand in DKI Jakarta Province, stated that in 2015 the total energy requirement is 79,461,652.24 Barrel of Oil Equivalent (BOE). Based on the total energy demand BaU scenario of 146,609,361.13 BOE by 2025, while based on the KEN scenario of $123,642,522.09 \mathrm{BOE}$ in the same year. Based on the total energy demand $\mathrm{BaU}$ scenario of $279,492,827.01$ BOE by 2050 , while based on the KEN scenario of $173,378,026.77 \mathrm{BOE}$ in the same year. Based on the results of both scenarios, the total energy demand in DKI Jakarta Province has always increased threefold by 2050 compared to the base year.
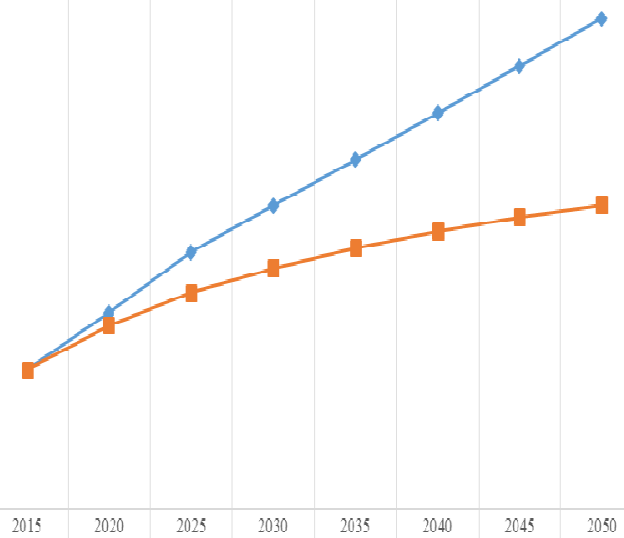
$\rightarrow$ - BAU 79.461.652, 112.202 .015 146.609.361 173.096.353 199.206.748 225.614.298 252.420.253 279.493.827

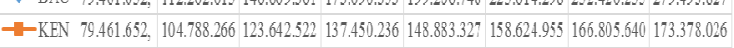

Fig 1. Graph of All Energy Requirement in DKI Jakarta Province

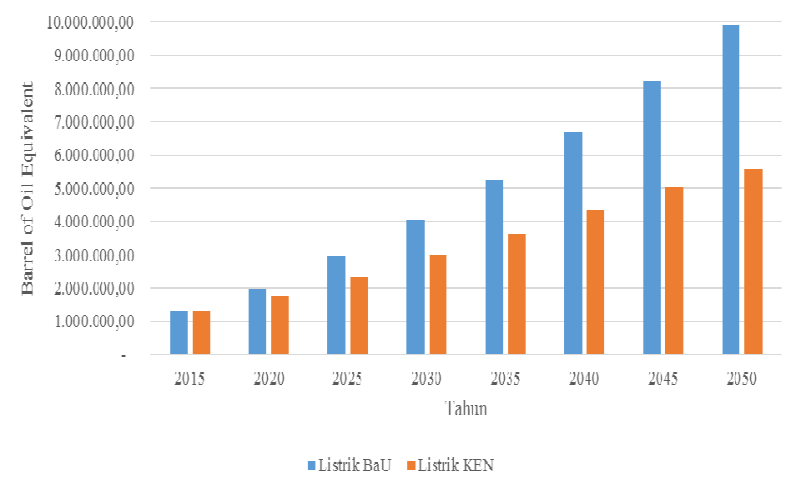

Fig 2. Graph of the Relationship Between Demand for Electrical Energy Against Year of Projection

Fig 2. explained about the demand of electric energy in DKI Jakarta Province in both scenarios. Demand for electrical energy is one type of energy transformation in the calculation and analysis of all energy needs in Jakarta. Under the scenario of BaU and KEN by 2015, the magnitude of demand for electrical energy is 1,283,211.79 BOE. Based on the scenario of $\mathrm{BaU}$ demand for electricity energy in 2025 amounted to $2,952,903.21$ BOE or doubled compared to base year, whereas based on KEN scenario of electrical energy demand in 2025 amounted to 2,309,170.31 in the same year. Under the scenario of $\mathrm{BaU}$ the demand for electrical energy in 2050 amounted to 9,902,955.84 BOE or increased almost eightfold compared to base year, while based on KEN scenario of electricity demand in 2050 amounted to 5,598,140.94 or increased fourfold compared to the year basic.

The BaU and KEN scenarios about the demand for electrical energy from the household, industrial, commercial and transportation sectors as well. The highest energy demand is from the transport sector at $40,862,007.59$ BOE in both scenarios by 2015 and the lowest energy demand from the commercial sector amounted to $6,277,133.11$ BOE in the same year. Based on the $\mathrm{BaU}$ scenario of energy demand from each sector in a row of $32,594,850.65 \mathrm{BOE}$; 29.025.182,26 BOE; 14.444.822,51 BOE; and 70,544,505.71 BOE by 2025, while based on the KEN scenario of energy demand from each sector respectively totaling 24,330,576.94 BOE; 25,561,755.12 BOE; 11,413,907.37 BOE; and $62,336,282.64$ BOE in the same year. Based on the BaU scenario the energy demand of each sector is respectively $67,958,159.93 \mathrm{BOE} ; 41.653 .607,19 \mathrm{BOE}$; 40.238.929,60 BOE; and 111,488,743.40 BOE by 2050, while based on the KEN scenario of energy demand from each sector in a row of 45,497,533.39 BOE; 26,699,776.05 BOE; 27.384.626,76 BOE; and $73,796,090.54 \mathrm{BOE}$ in the same year.

\subsection{Energy balance BaU and KEN}

The balance between demand and energy supply in DKI Jakarta area has been calculated from the data - data that has been collected from various sources that can be accounted for. Based on the calculation with econometric approach and end-use pendektan in this research is that energy requirement in DKI Jakarta experiencing energy deficit. energy management that must be done by DKI Jakarta Provincial Government is by making policy that energy import from surrounding area of kawsan DKI Jakarta that can conduct electricity energy production and there is excess electrical energy in the area so that electric energy can be used in DKI Jakarta area. The areas around DKI Jakarta that can meet the electricity needs for the DKI Jakarta area are in Banten Province and West Java Province. Both provisions will certainly produce more electrical energy compared to DKI Jakarta Province. 
Based on data from Statistics of Electricity No. 30 of 2017, the installed capacity of PLN power plant in Banten Province is 6,309.80 MW and West Java Province is 6,270.36 MW while DKI Jakarta is 3,748.40 MW in 2016. Installed capacity of IPP power plant (Independent Power Producer) and PPU (Private Power Utility) Banten Province area of 628.00 MW and 887.69 MW, while West Java Province of 2,020.52 MW and $629,80 \mathrm{MW}$ and additional IO power plant (Operating Permit) amounting to $39,00 \mathrm{MW}$ in 2016. PLN electricity production area of Banten Province amounted to $0.45 \mathrm{GWh}$ and West Java Province amounted to 25,349.37 GWh in 2016. Rent and purchase of electrical energy from outside PLN Banten Province of 23.54 GWh and West Java Province amounted to 200.71 GWh in 2014. Power connected PLN Banten Province area of 9,379.20 MVA and West Java Province of 22,178.50 MVA while DKI J akarta of 16,964.36 MW in 2016. The electricity consumption of PLN in all sectors of Banten Province is 20,368,56 GWh and West Java Province is 46,143,23 GWh while DKI Jakarta is 31,293,75 GWh in 2016. The number of PLN customers from all Banten Province sector sector of 2,742,013 customers and West Java Province of 12,057,209 customers while DKI Jakarta amounted to 4,009,982 customers in 2016. Electrification ratio of PLN Banten Province amounted to $99.91 \%$ and West Java Province of $97.81 \%$ while DKI Jakarta amounted to $99.98 \%$ in 2016 .

\section{Conclusion}

Results of the BaU and KEN scenarios by 2025 there are differences in some indicators of which are the total supply of energy sources; total energy transformation; and total energy demand. The total energy supply of coal in the $\mathrm{BaU}$ scenario is still $0.50 \%$, while in the KEN scenario there is a decrease in the use of coal which is only $0.07 \%$ of the total energy supply. The energy source of the gas in the BaU scenario is still $30.24 \%$. While in the scenario KEN increase reaches $36.57 \%$. The energy source of oil still dominates from both scenarios, in the BaU scenario reaches $53.49 \%$ while the KEN scenario has decreased slightly reaching $52.53 \%$. The energy source of EBT in both scenarios is still slightly contributed by $0.07 \%$ in the $\mathrm{BaU}$ scenario and $0.13 \%$ in the KEN scenario. The electrical energy source in the $\mathrm{BaU}$ scenario is only $15.70 \%$ and the KEN scenario is $10.71 \%$.

\section{Acknowledgements}

The authors would like to acknowledge the Department of System Engineering, Faculty of Engineering, Universitas Gadjah Mada for providing the facilities during this study.

\section{References}

1. B.K. Sovacool, E.E.S. Perf. E, 5846 (2011)

2. M. Zhang, Li H, M. Zhou, Mu H, Dec. Ana. Ene. C. 88, 2279 (2011)
3. V.S. Ediger, U. Camdah, Ene. Eff. Turk. Tran. 35, 1238 (2007)

4. Q. F. Erahman, W.W. Purwanto, M. Subandriyo, A. Hidayatno, Ass. Ind. Ene. Sec. Ind. Comp 111, 364 (2016)

5. M.H. Hasan, TMI. Mahlia, N. Hadi N. Rev. Ener. Sce. Sust. Ind 16, 2316 (2012)

6. Deendarlianto, et al, Sce. Analy. Ener. Tran 70, 13 (2017)

7. I. Natarianto et al, Pal. Bio. Pros. Ind 7, 110 (2017)

8. Leonard C. Sebastian, G. Iis, Me. Ref. Mil. Ind 29, 293 (2013)

9. John B. Haseman, Ind. Mil. Ref. Mor. Hum, 111 (2006)

10. Leonard C. Sebastian, G. Iis, Tak. Sto. Mi. Ref. Ind, 29 (2012)

11. A. M. Nasution, Rol. Fish. Ass. Mar. Enf. Age 8, 1 (2018)

12. Capt. Cathal O'Connor, Fpr. Hum. Ass. Dis. Ope 65, 1 (2012)

13. Leonard C. Sebastian, G. Iis, Ass. 12. Year. Mil. Ref. Ind, 227 (2011)

14. A. Muhammad, K. Yandry, Str. Cul. Ind. Mar. Sec 5, 77 2017)

15. K. Yandry, Vis. Por. Mar. 2, 11 (2016)

16. Leonard C. Sebastian, C. Yuddy, Def. Bud. Ind, 126 (2007)

17. F. Urban, R.M.J. Benders, H.C. Moll, Mod. Ener. Sys. Dev. Cou. 35, 3473 (2017)

18. Stockholm Environment Institute, Long-range Energy Alternative Planning System, User Guide. (Boston, Stockholm Environment Institute, 2006)

19. S. C. Bhattacharyya, G. R. Timilsina, Mod. Ene. Dem. Dev. Cou. Spe. Fea. Ade 38, 1979 (2010)

20. H. J. Song, S. Lee, at al, Env. Eco. Asse. Che. Abs. Pro 35, 5109 (2007)

21. JD. Dargaty, D. Gately, Inc. Eff. Veh. Own, 33, 101 (1999)

22. Y. Restianti, SH. Gheewala, Env. Lif. Cyc. Cos. Asse. Cas, 3, 1 (2012)

23. Suhono, Sarjiya, Long. Ele. Dem. For. Sum. Sys. Elec. Cons 68, 455 (2015)

24. Y. Restianti, SH. Gheewala, lif. Cyc. Asse. Gas. Ind, 17, 402 (2012)

25. A. Elias, K. Magnus, T. Patrik, P. Stevlana, Ene. End. Use. Eff. Pot. Amo. Swe 93, 165 (2018)

26. L. Yunbo, et al, End. Ene. Mod. Edg. Clo. Bas. Pla. App. Dat. Str. Ana 87, 667 (2018)

27. C. R. Rocio, T. S. D. Maria, Ana. Ene. End. Use. Eff. Pol 101, 436 (2017)

28. R. Zhengen, et al, Int. App. Mod. End. Use. Ene. Wat. Con 26, 344 (2016)

29. Z. Ren, P. Pavere, McNamara, Loc. Com. Lev. Phy. Bas. Mod. End. Use. Ene. Con 49, 586 (2012)

30. F. Kurniawan, N. Agung, W. Bambang, Pra. Keb. Ene. Lis. UPJ. Wil 9, 52 (2007)

31. A. T. Pradana, Pra. Keb. Ene. Lis. Are. Pel. Jar. Mal 1, 1 (2013)

32. M. Firdaus, Ekonometrika suatu pendekatan aplikatif (Jakarta, Bumi Aksara, 2004) 